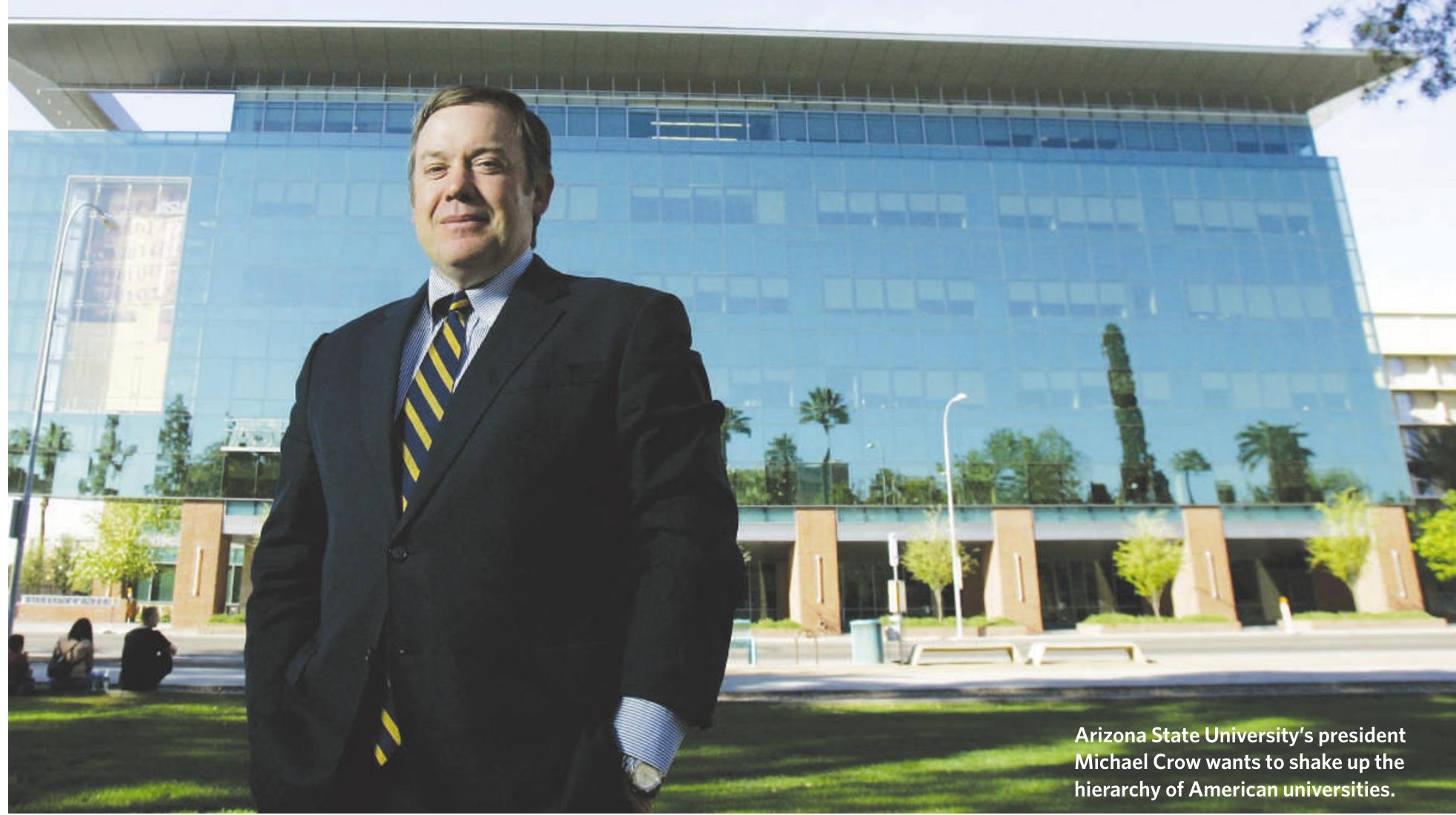

\title{
THE ARIZONA EXPERIMENT
}

\section{A shift in population, money and political influence to America's 'sunbelt states' is helping to reshape its research universities. The first of two features looks at the far-reaching ambitions of Arizona State University. The second asks whether a rush to create extra medical schools could spread the region's resources too thinly.}

$\mathrm{t}$ is a hot February morning in the Arizona desert, and Walter Cronkite, the legendary American newscaster, is straining every muscle in his 90 -year-old body to break the hard ground with a golden shovel.

Cronkite is in Phoenix to start construction on a new home for America's biggest journalism school, in America's largest university, in what will soon be its third-largest city. He has some generous words for his host, the president of Arizona State University (ASU). Michael Crow, Cronkite tells the crowd gathered for the ground-breaking, is "a true visionary of our time. He entered the city and took the reins of the university, and gave it direction and energy beyond what anyone could have imagined."

Strong words coming from the 'most trusted man in America' But the energy is palpable across ASU, including its campus here in downtown Phoenix where construction cranes speak to Crow's ambition. In the past four years, since he left Columbia University in New York to take the reins in Arizona, Crow has had one goal in mind. Put simply, he wants to leave behind the Harvard template, and build a new American university for the twenty-first century.

The key to Crow's vision is to break away from the department-based model of most universi- ties, and instead build up excellence at problemfocused, interdisciplinary research centres. US research universities, Crow argues, "are at a fork in the road: do you replicate what exists, or do you design what you actually need?" By his reckoning, centres that teach students to communicate with the public and to tackle real problems, such as water supply, are more relevant to today's needs than, say, a chemistry department.

Crow's ideas for ASU have some powerful supporters. "It has become a very different and very exciting institution," says Frank Rhodes, former president of Cornell University in New York and the one-time chair of the US National Science Board. "It is going to be a prototype for the rest of the country."

Not everyone is convinced. Some think that Crow has over-reached, attempting to turn a public university with a mixed reputation into a research hub of international repute. For instance, critics have attacked plans for a medical school in Phoenix - supported by Crow, but being built by Arizona State's erstwhile rival, the Tucson-based University of Arizona - as being extravagant and politically inspired (see page 971). In addition, Crow has been involved in noisy public disputes with ASU's student newspaper over allegations that he tried to censor its content to please Ira Fuller, a Mormon construction magnate who has donated more than US $\$ 160$ million to various university projects.

Before arriving at ASU, Crow had a reputation as a talented but headstrong university leader. A political scientist who specialized in science and technology policy at Iowa State University, he entered full-time university administration as a vice-provost at Columbia University, one of the top private research universities in the United States. There he helped to establish the Earth Institute - now led by economist Jeffrey Sachs - to tackle interdisciplinary environmental problems. He also pursued a vainglorious effort to save Biosphere 2, the Earth-sciences experiment-cum-greenhouse built in the Arizona desert and funded by Texan billionaire Ed Bass. It was his sojourns to Biosphere 2 that first drew him to the youngest and, arguably, brashest of the contiguous United States. "I liked the attitude here," Crow recalls.

Talk to any academic who has accepted or rejected a position at ASU recently - and there are plenty of them - and this attitude invariably comes to the fore. For your typical American university professor from either coast, the idea of moving to Phoenix is about as appealing as a stint in the nineteenth-century wild-west community 
portrayed on HBO's series Deadwood. Yet the size and the sheer energy of the city and the project can overcome initial misgivings. A surprising number of top-flight individuals - from Nobel-prize-winning economist Edward Prescott to the biologist and former research chief of SmithKline Beecham George Poste - have taken the plunge.

ASU was already growing its research from a modest base, with an interdisciplinary bent, before Crow turned up. In 2002, the university was involved in setting up the Translational Genomics Research Institute (TGen), a genetics research centre run by Jeffrey Trent, former scientific director of the US National Human Genome Research Institute. Today TGen has about 300 researchers, an annual research income of $\$ 60$ million, and eight spin-off companies under its belt.

Crow's role has been to publicly raise the flag of bold reform, get politicians and philanthropists on board, sign up some star academics and build interdisciplinary centres to house them. Those established under his tenure include the physically spectacular, \$150-million Biodesign Institute led by Poste; a School of Earth and Space Exploration (SESE), headed by geologist Kip Hodges; and the Consortium for Science, Policy and Outcomes run by Dan Sarewitz, a former Democrat staff member of the House of Representatives.

\section{Stylish approach}

The Biodesign Institute, whose building won $\mathrm{R} \& \mathrm{D}$ magazine's award last year for the finest new laboratory in the United States, houses 700 staff, including 100 faculty members who are collaborating, drug-industry style, on new approaches to molecular biology and genetics. Biology, computing and engineering in particular, but also law, social sciences and other specialties, are brought into the mix. Last year, the institute attracted about $\$ 60$ million in public research funding. If all goes to plan, two additional laboratory buildings will be built by 2009 , at a further total cost of $\$ 300$ million.

Poste has the air of someone more accustomed to giving orders than following them,

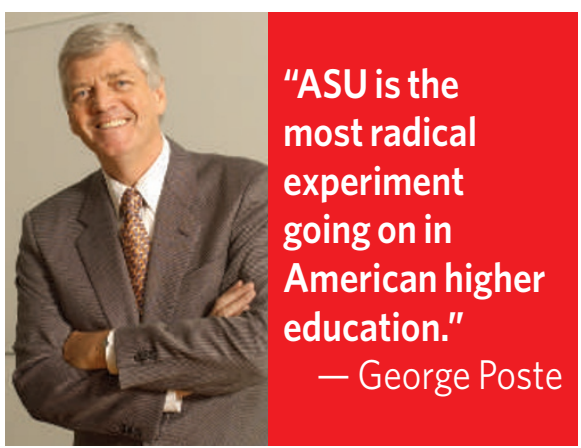

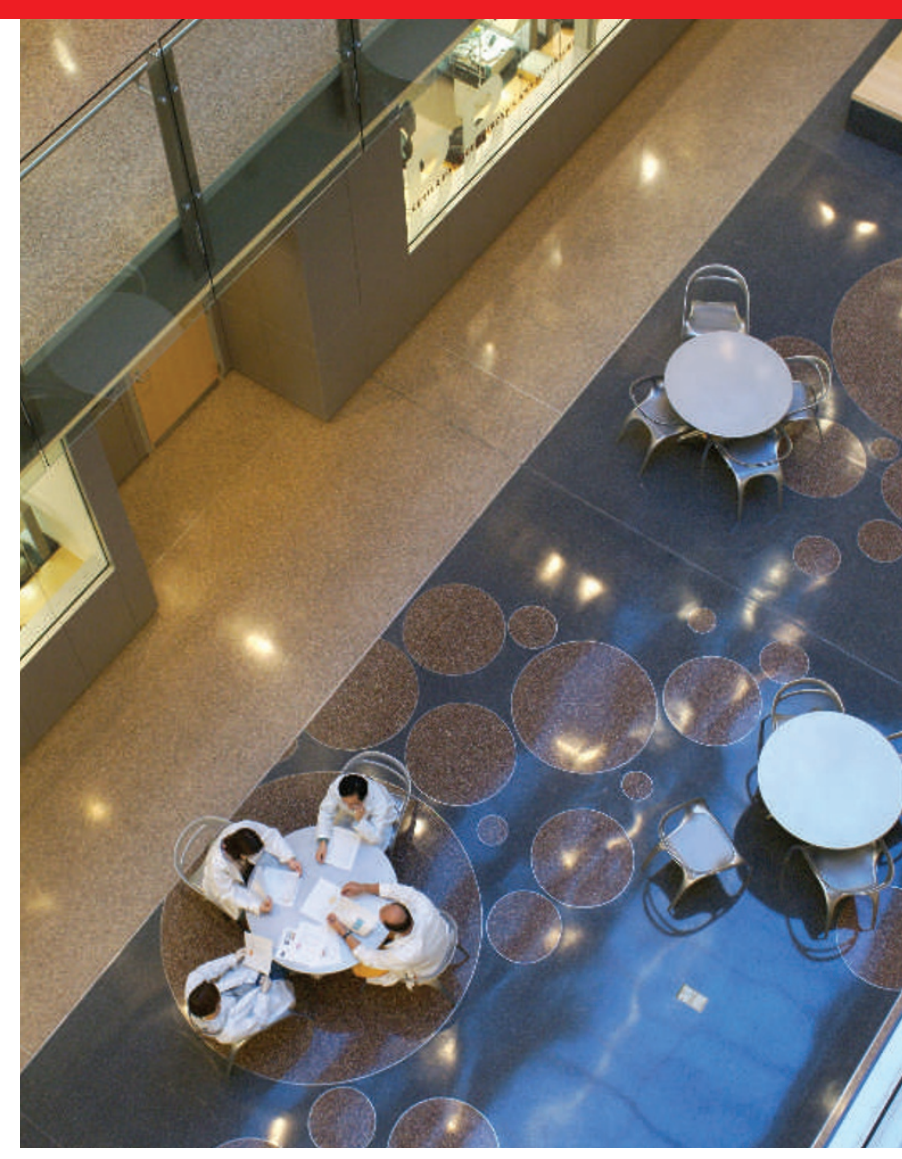

Arizona State University's Biodesign Institute is set up to foster collaborations between researchers. but, like many of Crow's recruits, he speaks with an almost-childlike enthusiasm for the project. ASU is "singularly the most radical experiment going on in American higher education", he says. "This is the fastest-growing metropolitan area in the United States, and its largest constellation of undergraduates. This isn't just about the research; it is about the future of these young people."

Michael Tracy, deputy director of the institute, admits that he hesitated before coming to Arizona from his previous position at Stanford Research International, a contract research group in California. But he says that he has been impressed by the extent to which Arizona's residents have bought into the university's plans. "Local people realize that the area needs a high-value proposition," he says. "They have really embraced the idea."

Kip Hodges, who came from Massachusetts Institute of Technology (MIT) in Cambridge last July to lead ASU's new School of Earth and Space Exploration, shares this enthusiasm. "It is a wonderful thing to be part of a place that is becoming, rather than a place that has been," he says of Phoenix.

SESE, which has 36 faculty from many disciplines, hopes to be in a new, purpose-built building by 2009. It aims to pull together expertise in engineering, computation and Earth and space science (ASU is a leader in Mars exploration) to obtain a better understanding of problems on this planet and farther afield. At first, Hodges suspected that ASU's emphasis on serving Phoenix was parochial — "after all, what has MIT ever done for Boston?” he asks rhetorically. "But for SESE, it is a matter of the relationships between the Earth and society." For example, the centre plans to study how society coevolves with changes in water resources. "It is obviously important for Phoenix, but it is important for the rest of the world, too," Hodges says. Addressing such problems requires a huge collection of skills, including archaeology, the physics and chemistry of water, evolution, anthropology, human ecology, climate and palaeoclimatology. The centre aims, for instance, to build a comprehensive model of the entire Colorado river basin.

\section{Heat islands}

Water issues are also to the fore at the Global Institute for Sustainability, an interdisciplinary centre led by Chuck Redman, an anthropologist and long-time ASU faculty member. The institute brings together about 50 faculty, all of whom also have departmental appointments, to study the relationship between people and the environment, especially in urban areas. A focus of interest, Redman says, is to develop building materials and coatings that are suited to 'heat island' cities such as Phoenix, where temperatures can exceed the surrounding area by as much as $8^{\circ} \mathrm{C}$.

Unlike these other centres, the Consortium for Science, Policy and Outcomes is a unit that Crow founded in Washington DC and brought with him to ASU. On Tuesday mornings, he even teaches class there, engaging in a double act with centre director Sarewitz in a three-hour seminar with about 30 undergraduate and graduate students. Crow's a talented teacher. He pulls students into Thomas Kuhn's ideas on how scientific paradigms change by 
alluding to a friend who died of the immune disease lupus, and illuminates policy questions by referring to people he knows, such as Jack Marburger, the US presidential science adviser, and Jim Collins, an ASU biologist who runs the National Science Foundation's biologicalsciences directorate.

All of this is part of an overall picture that puts strong precedence on three things: highquality, interdisciplinary research; access for large numbers of students from Phoenix's racially and socially diverse population; and relevance to the needs of the city and the region. Parts of the vision predate Crow's arrival, but the university has become very much Crow's project. "You have got to give him credit for attacking on multiple fronts simultaneously," says Trent.

\section{Fast forward}

Phoenix may be the ideal place to host the vision. "This is a university that is being built at the same time as the city is being built," says Crow. On a wall in his office, an aerial view displays the phenomenal growth of a city whose developed area already exceeds that of Los Angeles. The population of Phoenix and its suburbs has grown rapidly to nearly 4 million, and is projected to reach around 8 million within the next quarter century.

Yet for Crow and his disciples, this newness is the greatest part of the appeal. The city has no establishment to overthrow; even Los Angeles is an establishment town by comparison. Asked why people come here, Crow's answer is straightforward: "Quality of life," he says. For most of the city's youthful population that means space to live and drive, not opera or bookshops. That suits Crow, the son of an car mechanic, just fine: 'Someone once said to me, 'some of you blue-collar $\mathrm{PhDs}$ are quite smart," he recalls with glee.

The question of what kind of university will best serve this new American university is yet to be answered. The model Crow mentions most frequently is that of the University of London which, although now fraying, includes everything from the élite Imperial College to stalwart specialized colleges such as Goldsmiths and

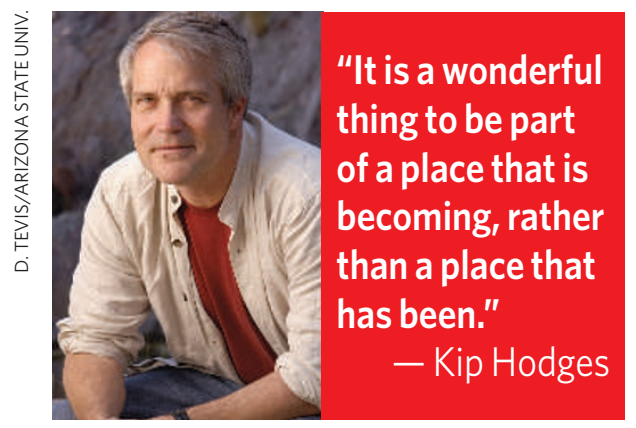

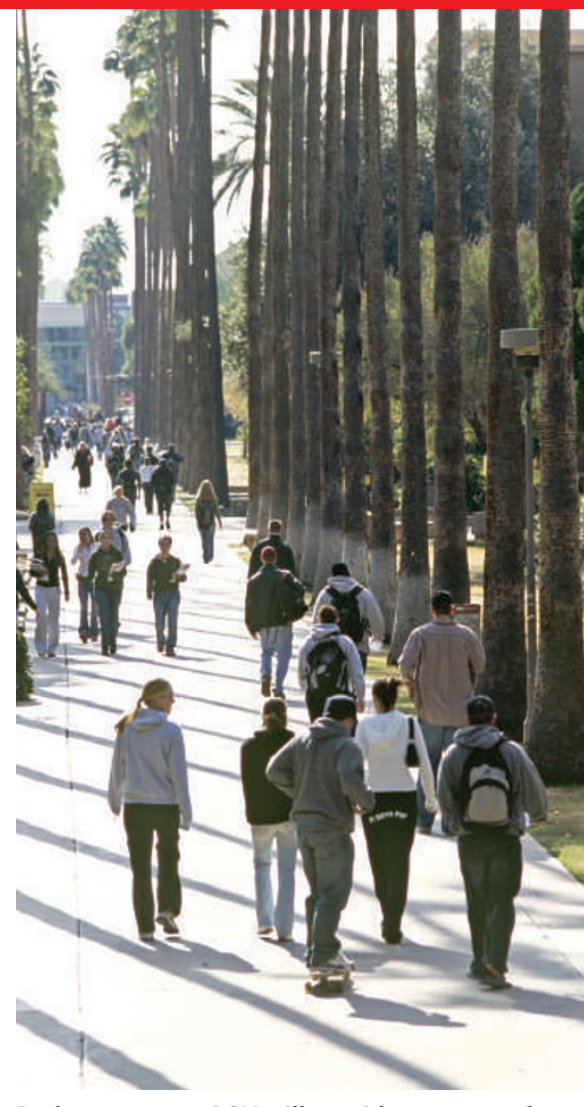

Path to success: ASU will provide resources for a diverse community.

Birkbeck, which provide vocational training and adult education.

Arizona, with its booming population and slim infrastructure, faces some of the same challenges as Victorian London - and it sees strong universities as part of the solution. The relationship between public universities and legislature in most American states is traditionally a difficult one. Universities are regarded by many state legislators as expensive and dangerous hotbeds of radicalism and free love (a relationship searingly portrayed by Jane Smiley - a friend and former Iowa State colleague of Crow's - in the comical novel Moo). But in Arizona, the free love is between the legislature and the state university system, of which ASU is the largest part.

Conservative lawmakers and the state's liberal governor, Janet Napolitano, are united in their support for the university's expansion. A state referendum in 2000 allocated $\$ 1.5$ billion in sales tax revenue over 20 years to research in the state university system. Two years later, the legislature gave $\$ 400$ million more.

And private money is flowing too. In a young city with a thin scholarly tradition, private philanthropy should be a hard sell. But the involvement of people like Fuller, who never attended the university but delivered newspapers near its main Tempe campus, and William Carey, a financier who gave $\$ 50$ million to ASU's business school in 2003, have shown that this door, too, can be prised open.

The programme still has its detractors. Academics who don't agree with the new interdisciplinary paradigm say that they have been trampled underfoot. Take Robert Pettit - a chemist and long-time director of the Cancer Research Institute at ASU until he lost the position in 2005. Pettit had clashed with Crow over various issues, including the relationship between his lab and new, interdisciplinary centres at the university. Still a tenured professor at ASU, Pettit says that the arrival of the new institutes "has been very destructive to faculty and student morale and has placed ASU in serious financial jeopardy".

Richard Zare, head of chemistry at Stanford University and another former chair of the National Science Board is, like Rhodes, an authority on US research universities. But he thinks that ASU's emphasis on the interdisciplinary may come unstuck. "It will learn, as others have in the past, that you can't have strong interdisciplinary programmes without strong departments," Zare says.

But to Crow, the hierarchy among established US university departments is too rigid. "If you are the 25th-best geology department, you are trapped!" he says. "Your chances of getting to be fifth-best are zero." The interdisciplinary approach, he says, offers more promise.

\section{Meaningful measures}

Measuring achievement for the new ASU falls to the university provost, Betty Capaldi. A typical Crow hire, Capaldi was already co-leader of a project that collates detailed, comparative statistics between US universities. So no one is likely to accuse her of fudging the numbers. Capaldi, however, is rather coy about how the performance of the new ASU should be measured. The centres can "use anything they find meaningful", she suggests. "We are asking every unit to talk to us about how they would measure success. If you are unique - compare yourself to yourself," she says.

It will take years to determine whether the experiment has been a success. Senior ASU faculty assert that the commitment to interdisciplinary research and broad student access have already developed deep roots at the university. And the enthusiasm that it has rekindled in such diverse and seasoned characters as Walter Cronkite and George Poste is certainly infectious.

But the entire project undoubtedly hangs on Crow's unique style of leadership. The approach is unusual, as Rhodes notes, because presidents of US universities often have to content themselves with refining what they have already got. "The polishing of the status quo is much more comfortable," he says. At ASU, he says, "there is a kind of rugged individualism that says - we will just make this happen." Colin Macilwain is a reporter and editor for Nature based in Edinburgh. 